\title{
Ácido fumárico e sua combinação com os ácidos butírico ou fórmico em dietas de leitões recém-desmamados
}

\author{
[Fumaric, butyric and formic acid combinations in feed formulation for recently weaned piglets] \\ F.E. Gomes ${ }^{1}$, D.O. Fontes ${ }^{2 *}$, E.O.S. Saliba ${ }^{2}$, W.M. Ferreira ${ }^{2}$, E.T. Fialho ${ }^{3}$, \\ F.C.O. Silva ${ }^{4}$, M.A. Silva ${ }^{2}$, G.S.S. Corrêa ${ }^{2}$, G.M. Salum ${ }^{5}$ \\ ${ }^{1}$ Departamento de Zootecnia-CCA-UFRR - Boa Vista, RR \\ ${ }^{2}$ Escola de Veterinária - UFMG \\ Caixa Postal 567 \\ 30123-970 - Belo Horizonte, MG

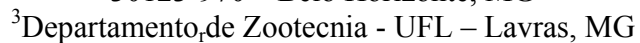 \\ ${ }^{4}$ EPAMIG - Viçosa, MG \\ ${ }^{5}$ Aluno de graduação - EV-UFMG - Belo Horizonte, MG
}

\begin{abstract}
RESUMO
Avaliaram-se o desempenho e as características morfológicas e morfométricas do intestino delgado de 210 leitões, desmamados aos 15 dias de idade, com peso médio inicial 4,04 $\pm 0,66 \mathrm{~kg}$, em dois períodos experimentais (15-30 e 15-36 dias de idade). O delineamento experimental foi em blocos ao acaso, com sete tratamentos (T1: ração-controle sem adição de acidificante; T2: ração-controle $+0,5 \%$ de ácido fumárico; T3: ração-controle $+1,0 \%$ de ácido fumárico; T4: ração-controle $+0,5 \%$ de ácido fumárico $+0,1 \%$ de ácido butírico; T5: ração-controle $+0,5 \%$ de ácido fumárico $+0,5 \%$ de ácido fórmico; T6: ração-controle $+1,0 \%$ de ácido fumárico $+0,1 \%$ de ácido butírico e $\mathrm{T} 7$ : ração-controle $+1,0 \%$ de ácido fumárico $+0,5 \%$ de ácido fórmico), cinco repetições e seis animais por unidade experimental. $\mathrm{O}$ peso dos leitões aos 30 dias de idade não foi influenciado pelos tratamentos, mas houve efeito significativo de tratamento sobre ganho de peso e consumo alimentar diário no período de 15-30 dias de idade, com maior desempenho para os leitões alimentados com dietas suplementadas com ácido fumárico. Não houve efeito significativo dos tratamentos sobre o peso médio aos 36 dias, o ganho de peso, o consumo diário e a conversão alimentar dos leitões de 15 a 36 dias de idade. Houve diferença entre tratamentos para a altura do epitélio do duodeno, porém não houve diferença em relação à do jejuno e à do íleo. As eletromicrografias do duodeno dos leitões alimentados com as diferentes dietas experimentais revelaram vilosidades com características normais.
\end{abstract}

Palavras-chave: leitão, ácido orgânico, desempenho, intestino delgado

\begin{abstract}
Performance, morphological and morphometric characteristics of the small intestine of 210 recently weaned piglets, averaging $4.04 \pm 0.66 \mathrm{~kg}$, during two periods (from 15 to 30 days of age and from 15 to 36 days of age) were evaluated in a randomized block experimental design with seven treatments, T1: control diet (CD); T2: $C D+0.5 \%$ fumaric acid; $T 3: C D+1.0 \%$ fumaric acid; $T 4: C D+0.5 \%$ fumaric acid $+0.1 \%$ butyric acid; T5: $C D+0.5 \%$ fumaric acid $+0.5 \%$ formic acid; $T 6: C D+1,0 \%$ fumaric acid $+0.1 \%$ butyric acid and $T 7$ : $C D+1.0 \%$ fumaric acid $+0.5 \%$ formic acid, five replicates and six piglets per experimental unit. No effects of treatment $(P<0.05)$ on body weight at 30 days of age was observed but significant differences between treatments were observed for daily weight gain and feed consumption from 15 to 30 days of age. Piglets fed supplemented acid fumaric diets had higher performance during this period. No significant effects of treatments on body weight at 36 days of age, daily weight gain, daily feed intake and feed conversion were
\end{abstract}

Recebido em 26 de fevereiro de 2007

Aceito em 24 de agosto de 2007

*Autor para correspondência (corresponding author)

E-mail: dalton@vet.ufmg.br 
observed $(P>0.05)$ from 16 to 36 days of age. Significant differences $(P<0.05)$ between treatments for duodenal epithelium height were observed, but not for jejunum and ileum epithelium heights. Normal villus patterns were observed in the electromicrographs of duodenum from piglets fed all different diets.

Keywords: piglet, organic acid, performance, small intestine, morphology

\section{INTRODUÇÃO}

Na suinocultura moderna, o desmame dos leitões é realizado de maneira prática e econômica, entre 14 e 28 dias de idade. A redução da idade do desmame consiste no modo mais efetivo de aumentar o número de ciclos reprodutivos anuais. A diminuição da idade de desmame, entretanto, tem contribuído para aumentar o estresse pós-desmame (Leibbrant et al., 1976).

O estresse provocado pela separação brusca dos leitões de suas mães, o estabelecimento de nova ordem social entre os animais, as mudanças no ecossistema do leitão e as modificações na fonte e na forma do alimento podem acarretar diminuição no consumo de dieta e no ganho de peso dos leitões jovens (Freitas et al. 1995). Em decorrência desse estresse, ocorrem atrofia das vilosidades intestinais e diarréia, que diminuem a capacidade digestiva e absortiva, e causam redução do ganho de peso dos suínos (Cera et al., 1988).

Atualmente, há crescente restrição ao uso de antibióticos promotores de crescimento na alimentação das aves e suínos (Mroz, 2003). O desenvolvimento de resistência bacteriana aos antibióticos usados como promotores de crescimento e a possibilidade de resistência cruzada entre patógenos animais e humanos reforçam a necessidade de busca de alternativas mais seguras e mais aceitáveis pela sociedade (Overland et al., 2000). Tais alternativas deverão respeitar os requerimentos do consumidor moderno e as crescentes demandas por segurança alimentar.

Os promotores de crescimento e os ácidos orgânicos, que são formas alternativas aos antibióticos para formulação das dietas de aves e suínos, têm merecido a atenção dos pesquisadores e das empresas que comercializam rações. Do ponto de vista prático e econômico, os ácidos orgânicos e seus sais são as formas alternativas que promovem melhores resultados no desempenho de suínos (Mroz, 2003).
O objetivo deste experimento foi avaliar o efeito dos ácidos fumárico, butírico e fórmico sobre o peso aos 30 e 36 dias de idade, o ganho de peso, o consumo e a conversão alimentar de 15 a 30 e de 15 a 36 dias de idade, sobre a morfologia e morfometria do intestino delgado aos 36 dias de idade de leitões, desmamados aos 15 dias.

\section{MATERIAL E MÉTODOS}

O desempenho e as características morfológicas e morfométricas de 210 leitões de linhagem comercial, selecionados geneticamente para deposição de carne magra na carcaça, desmamados aos 15 dias de idade e com peso inicial médio de $4,04 \pm 0,66 \mathrm{~kg}$, foram avaliados em dois períodos experimentais (15-30 e 15-36 dias de idade) em delineamento experimental de blocos ao acaso, com sete tratamentos (T1: ração-controle sem adição de acidificante; T2: ração-controle $+0,5 \%$ de ácido fumárico; T3: ração-controle $+1,0 \%$ de ácido fumárico; T4: ração-controle $+0,5 \%$ de ácido fumárico $+0,1 \%$ de ácido butírico; T5: raçãocontrole $+0,5 \%$ de ácido fumárico $+0,5 \%$ de ácido fórmico; T6: ração-controle $+1,0 \%$ de ácido fumárico $+0,1 \%$ de ácido butírico e $\mathrm{T} 7$ : raçãocontrole $+1,0 \%$ de ácido fumárico $+0,5 \%$ de ácido fórmico), cinco repetições e seis animais por unidade experimental. Adotou-se como critério para formação de blocos, o peso inicial dos leitões.

As dietas experimentais isoenergéticas e isoprotéicas (Tab. 1) foram formuladas para exceder as exigências de suínos na fase pré-inicial, de acordo com NRC (Nutrient..., 1998). As dietas experimentais foram produzidas a partir de uma dieta basal (T1) com 20,4\% de proteína e $3400 \mathrm{kcal} / \mathrm{kg}$ de energia metabolizável. As dietas e a água foram fornecidas à vontade.

Para avaliação do desempenho do lote foram considerados o peso aos 30 e aos 36 dias de idade e o ganho de peso diário (GPD), o consumo de ração diário (CRD) e a conversão alimentar (CA) durante dois períodos experimentais (15-30 e 15-36 dias de idade). As dietas foram pesadas no início e ao término de cada período experimental, pesaram-se, também, as sobras para avaliação de o consumo alimentar diário. 
Tabela 1. Composição percentual das dietas experimentais fornecidas aos leitões durante o período experimental de 15-36 dias de idade

\begin{tabular}{|c|c|c|c|c|c|c|c|}
\hline & $\mathrm{T} 1$ & $\mathrm{~T} 2$ & T3 & $\mathrm{T} 4$ & T5 & T6 & $\mathrm{T} 7$ \\
\hline Milho (7,8\% PB) & 25,038 & 25,038 & 25,038 & 25,038 & 25,038 & 25,038 & 25,038 \\
\hline Farelo de soja ( $46 \%$ PB) & 24,20 & 24,20 & 24,20 & 24,20 & 24,20 & 24,20 & 24,20 \\
\hline Caulim & 1,50 & 1,00 & 0,50 & 0,67 & 0,50 & 0,17 & 0,00 \\
\hline Açúcar & 6,00 & 6,00 & 6,00 & 6,00 & 6,00 & 6,00 & 6,00 \\
\hline Óleo de soja refinado & 3,20 & 3,20 & 3,20 & 3,20 & 3,20 & 3,20 & 3,20 \\
\hline Concentrado $40 \%$ & 40,00 & 40,00 & 40,00 & 40,00 & 40,00 & 40,00 & 40,00 \\
\hline DL metionina (99\%) & 0,014 & 0,014 & 0,014 & 0,014 & 0,014 & 0,014 & 0,014 \\
\hline L-treonina $(98,5 \%)$ & 0,048 & 0,048 & 0,048 & 0,048 & 0,048 & 0,048 & 0,048 \\
\hline Ácido fumárico $(99 \%)$ & - & 0,5 & 1 & 0,5 & 0,5 & 1 & 1 \\
\hline Ácido butírico (33\%) & - & - & - & 0,33 & - & 0,33 & - \\
\hline Ácido fórmico $(85 \%)$ & - & - & - & - & 0,5 & - & 0,5 \\
\hline Total $(\mathrm{kg})$ & 100,00 & 100,00 & 100,00 & 100,00 & 100,00 & 100,00 & 100,00 \\
\hline \multicolumn{8}{|c|}{ Valor nutricional calculado (\% na matéria natural) } \\
\hline $\begin{array}{l}\text { Energia metabolizável } \\
(\mathrm{kcal} / \mathrm{kg})\end{array}$ & 3.400 & 3.400 & 3.400 & 3.400 & 3.400 & 3.400 & 3.400 \\
\hline Proteína bruta $(\%)$ & 20,45 & 20,45 & 20,45 & 20,45 & 20,45 & 20,45 & 20,45 \\
\hline Cálcio (\%) & 0,57 & 0,57 & 0,57 & 0,57 & 0,57 & 0,57 & 0,57 \\
\hline Fósforo disponível (\%) & 0,47 & 0,47 & 0,47 & 0,47 & 0,47 & 0,47 & 0,47 \\
\hline Lisina total $(\%)$ & 1,56 & 1,56 & 1,56 & 1,56 & 1,56 & 1,56 & 1,56 \\
\hline Met + cis total $(\%)$ & 0,88 & 0,88 & 0,88 & 0,88 & 0,88 & 0,88 & 0,88 \\
\hline Treonina total $(\%)$ & 1,01 & 1,01 & 1,01 & 1,01 & 1,01 & 1,01 & 1,01 \\
\hline Triptofano total $(\%)$ & 0,25 & 0,25 & 0,25 & 0,25 & 0,25 & 0,25 & 0,25 \\
\hline
\end{tabular}

T1: ração-controle sem adição de acidificante; T2: ração-controle $+0,5 \%$ de ácido fumárico; T3: ração-controle + 1,0\% de ácido fumárico; T4: ração-controle $+0,5 \%$ de ácido fumárico $+0,1 \%$ de ácido butírico; T5: ração-controle + $0,5 \%$ de ácido fumárico $+0,5 \%$ de ácido fórmico; T6: ração-controle $+1,0 \%$ de ácido fumárico $+0,1 \%$ de ácido butírico e T7: ração-controle $+1,0 \%$ de ácido fumárico $+0,5 \%$ de ácido fórmico.

${ }^{1}$ Níveis de garantia (por kg/produto) - biotina: 1,5mg; ácido fólico: $3 \mathrm{mg}$; ácido pantotênico: $105 \mathrm{mg}$; cobalto $0,49 \mathrm{mg}$; vit.A: 40.500UI; aditivo antioxidante: $312 \mathrm{mg}$; vit.D3: $8.100 \mathrm{UI}$; vit.K3: $18 \mathrm{mg}$; selênio: $1,9 \mathrm{mg}$; colina: $1.800 \mathrm{mg}$; promotor de cescimento: $750 \mathrm{mg}$; ferro: $344 \mathrm{mg}$; vit.B12: $150 \mathrm{mcg}$; vit.B1: $6 \mathrm{mg}$; vit.E: $181 \mathrm{UI}$; zinco: $6.250 \mathrm{mg}$; niacina: 150mg; iodo: 3,81mg; vit.B6: 12mg; manganês: 129mg; vit.B2 18mg; cálcio (máx.): 5\%; fósforo (mín.): 1\%; extrato etéreo (mín.): 1,5\%; matéria fibrosa (máx.): 3\%; matéria mineral (máx.): 16\%.

Para avaliação das características morfológicas e morfométricas do intestino delgado dos animais, aos 36 dias de idade, foram abatidos três animais por tratamento, selecionados aleatoriamente, para coleta de segmentos do intestino delgado (duodeno, jejuno e íleo).

Após o abate de cada animal, retiraram-se dois fragmentos de aproximadamente $2 \mathrm{~cm}$ de comprimento, do duodeno, jejuno e íleo. $\mathrm{O}$ primeiro correspondendo a $10 \mathrm{~cm}$ da inserção com o estômago (duodeno) e o segundo a $50 \%$ do comprimento do intestino delgado (jejuno e íleo). Os fragmentos foram imediatamente lavados em água destilada, identificados e fixados em solução de formol tamponado a 10\%, para futuras análises.
As amostras foram preparadas segundo a técnica descrita por Junqueira e Junqueira (1983), seguindo as etapas de desidratação, diafanização, inclusão em parafina, microtomia e coloração dos cortes. Foram confeccionadas duas lâminas por região coletada, com dois cortes cada. As análises morfométricas dos cortes histológicos foram realizadas em microscópio óptico com aumento de 40 vezes. Para medição da altura do epitélio utilizou-se analisador de imagem Imagepro Plus 1.3.2.

Para a microscopia eletrônica de varredura, as amostras intestinais de duodeno, com aproximadamente $2 \mathrm{~cm}$ de comprimento, foram fragmentados a $0,5 \mathrm{~cm}$ e fixadas por 24 horas a $4^{\circ} \mathrm{C}$ em solução de glutaraldeído a $2,5 \%$ em tampão fosfato $(0,1 \mathrm{M}, \mathrm{pH} 7,4)$ e pós-fixadas em tetróxido de ósmio a $1 \%$ por 2 horas. A seguir, 
foram desidratados em série de concentração crescente de etanol (70 a 100\%). As amostras foram submetidas ao ponto crítico de secagem, utilizando $\mathrm{CO}_{2}$, montadas em suporte, metalizadas com ouro paládio e examinadas em microscópio eletrônico de varredura. Para observação das vilosidades, as amostras foram eletronmicrografadas.

Os dados de desempenho e das análises morfométricas foram analisados utilizando-se o pacote estatístico computacional SAEG
(Sistema..., 2000) e as médias dos tratamentos comparadas pelo teste SNK, com $5 \%$ de probabilidade.

\section{RESULTADOS E DISCUSSÃO}

O peso dos leitões, o ganho de peso, o consumo de ração diário e a conversão alimentar ao final de cada período do experimento, são apresentados nas Tab. 2 e 3.

Tabela 2. Peso inicial (PI), peso final (PF), ganho de peso diário (GPD), consumo de ração diário (CRD) e conversão alimentar (CA) de leitões dos 15 aos 30 dias de idade

\begin{tabular}{|c|c|c|c|c|c|}
\hline Tratamento & PI (kg) & $\mathrm{PF}(\mathrm{kg})$ & $\begin{array}{l}\mathrm{GPD}^{1} \\
(\mathrm{~kg} / \mathrm{d})\end{array}$ & $\begin{array}{c}\text { CRD } \\
(\mathrm{kg} / \mathrm{d})\end{array}$ & CA \\
\hline T1 - controle & 4,01 & 6,39 & $0,174 \mathrm{~b}$ & $0,218 b$ & 1,24 \\
\hline T2 - ácido fumárico $(0,5 \%)$ & 4,03 & 6,80 & $0,223 \mathrm{a}$ & $0,257 \mathrm{a}$ & 1,14 \\
\hline T3 - ácido fumárico $(1,0 \%)$ & 3,95 & 6,60 & $0,211 b$ & $0,254 \mathrm{a}$ & 1,17 \\
\hline T4 - ácido fumárico $(0,5 \%)+$ ácido butírico $(0,1 \%)$ & 4,24 & 6,58 & $0,177 \mathrm{~b}$ & $0,222 b$ & 1,25 \\
\hline T5 - ácido fumárico $(0,5 \%)+$ ácido fórmico $(0,5 \%)$ & 4,02 & 6,49 & $0,183 b$ & $0,218 b$ & 1,18 \\
\hline T6 - ácido fumárico $(1,0 \%)+$ ácido butírico $(0,1 \%)$ & 4,01 & 6,53 & $0,189 b$ & $0,220 \mathrm{~b}$ & 1,15 \\
\hline $\mathrm{T} 7$ - ácido fumárico $(1,0 \%)+$ ácido fórmico $(0,5 \%)$ & 4,01 & 6,30 & $0,173 \mathrm{c}$ & $0,218 b$ & 1,30 \\
\hline Coeficiente de variação (\%) & & 7,37 & 13,49 & 10,10 & 9,36 \\
\hline
\end{tabular}

Médias seguidas de letras distintas na coluna diferem entre si pelo teste $\mathrm{SNK}(\mathrm{P}<0,05)$.

${ }^{1}$ Contrastes estudados: T1 com T2; T1 com T3; T2 com T4; T2 com T5; T3 com T6 e T3 com T7.

Os tratamentos não influenciaram $(\mathrm{P}>0,05)$ o peso dos leitões aos 30 dias de idade. Entretanto, comparando-se os contrastes $\mathrm{T} 1$ com $\mathrm{T} 2$ observou-se que os leitões alimentados com dietas contendo ácido fumárico a $0,5 \%$ apresentaram maior GPD que os animais do T1 (dieta controle). No contraste T1 com T3, não houve diferença entre os animais tratados com a dieta contendo $1 \%$ de ácido fumárico e a dieta controle. No contraste T2 com T4, observou-se que leitões que receberam dietas com a associação do ácido fumárico $(0,5 \%)+$ ácido butírico $(0,1 \%)$ apresentaram desempenho inferior aos leitões que receberam dietas com apenas ácido fumárico $(0,5 \%)$. No contraste T2 com T5, observou-se que leitões que receberam dietas com a associação do ácido fumárico $(0,5 \%)+$ ácido fórmico $(0,5 \%)$ apresentaram menor GPD em relação aos que receberam dieta com apenas ácido fumárico $(0,5 \%)$. No contraste T3 com T6, não houve diferença entre o GPD dos leitões que receberam dietas com ácido fumárico $(1,0 \%)$ e aqueles tratados com dietas contendo a associação do ácido fumárico $(1,0 \%)$ e ácido butírico $(0,1 \%)$. Nos contrastes T3 e T7, observou-se que leitões alimentados com dietas contendo apenas ácido fumárico $(1,0 \%)$ apresentaram maior desempenho que os tratados com dietas contendo a associação entre o ácido fumárico $(1,0 \%)$ e ácido fórmico $(0,5 \%)$. Portanto, o GPD foi maior para leitões alimentados com dietas contendo apenas ácido fumárico a $0,5 \%$. Maior CRD, durante o período de 15-30 dias, foi observado para leitões alimentados com dietas suplementadas apenas com ácido fumárico.

Kirchgessner e Roth (1982), obervaram maior desempenho de leitões recém-desmamados alimentados com dietas suplementadas com 1,5 a $2,0 \%$ de ácido fumárico. Giesting e Easter (1985), ao adicionarem ácido fumárico nas proporções de 1, 2, 3 e 4\% nas dietas de leitões, observaram que a suplementação melhorou o ganho de peso e a conversão alimentar dos leitões, com máximo desempenho nos animais alimentados com 3\% de ácido fumárico. Silveira (2004) não observou efeito de dietas suplementadas com níveis de $0,5,1,0,1,5$ e 2,0\% de ácido fumárico sobre o desempenho de leitões desmamados aos 20 dias de idade. 
Tabela 3. Peso inicial (PI), peso final (PF), ganho de peso médio diário (GPD), consumo de ração médio diário (CRD) e conversão alimentar (CA) de leitões dos 15 a 36 dias de idade

\begin{tabular}{lrrrrr}
\hline \multicolumn{1}{c}{ Tratamento } & \multicolumn{1}{c}{$\begin{array}{c}\text { PI } \\
(\mathrm{kg})\end{array}$} & $\begin{array}{r}\text { PF } \\
(\mathrm{kg})\end{array}$ & $\begin{array}{r}\text { GPD } \\
(\mathrm{kg} / \mathrm{d})\end{array}$ & $\begin{array}{c}\text { CRD } \\
(\mathrm{kg} / \mathrm{d})\end{array}$ & CA \\
\hline T1 - controle & 4,01 & 9,52 & 0,263 & 0,317 & 1,20 \\
T2 - ácido fumárico $(0,5 \%)$ & 4,02 & 10,19 & 0,293 & 0,348 & 1,19 \\
T3 - ácido fumárico $(1,0 \%)$ & 3,95 & 9,68 & 0,274 & 0,334 & 1,21 \\
T4 - ácido fumárico $(0,5 \%)+$ ácido butírico $(0,1 \%)$ & 4,24 & 9,56 & 0,248 & 0,314 & 1,26 \\
T5 - ácido fumárico (0,5\%) + ácido fórmico (0,5\%) & 4,02 & 9,63 & 0,267 & 0,324 & 1,22 \\
T6 - ácido fumárico (1,0\%) + ácido butírico (0,1\%) & 4,01 & 9,89 & 0,280 & 0,328 & 1,17 \\
T7 - ácido fumárico (1,0\%) + ácido fórmico (0,5\%) & 4,01 & 9,16 & 0,245 & 0,313 & 1,28 \\
$\quad$ Coeficiente de variação (\%) & & 7,92 & 12,77 & 8,89 & 7,11 \\
\hline
\end{tabular}

Não houve diferença entre as médias pelo teste SNK $(\mathrm{P}>0,05)$.

Não se observou efeito significativo dos tratamentos sobre peso aos 36 dias e sobre GPD, CRD e CA dos 15-36 dias de idade de leitões. Resultados semelhantes foram verificados por Radecki et al. (1988), Risley et al. (1991), Krause et al. (1994), e Silveira (2004), em ensaios com inclusão de ácido fumárico em dietas de leitões na fase de creche. Contudo, resultados diferentes foram encontrados por Giesting e Easter (1985) que verificaram aumento significativo do ganho de peso quando adicionaram $3 \%$ ou $4 \%$ de ácido fumárico, porém não observaram efeito significativo para os níveis de $1 \%$ ou $2 \%$. Kirchgessner e Roth (1982) obtiveram respostas significativas tanto para consumo de dieta como para ganho de peso em vários experimentos que avaliaram o ácido fumárico para leitões recém-desmamados.

Ette et al. (2004) não verificaram efeito significativo sobre consumo de dieta, ganho de peso e conversão alimentar, quando utilizaram $1,2 \%$ ou $2,4 \%$ de diformato de potássio. Os mesmos autores, em outro experimento utilizaram dietas suplementadas com 1,2\% de ácido fórmico ou $1,2 \%$ de ácido sórbico e observaram que o consumo de dieta e o ganho de peso não foram influenciados pelos tratamentos, porém, os animais do grupo tratado com 1,2\% de ácido fórmico apresentaram melhor conversão alimentar. McInttyre et al. (1993), ao trabalharem com leitões desmamados aos 26 dias de idade, observaram que a suplementação de butirato de sódio melhorou o ganho diário em até $17 \%$ e aumentou o consumo e a conversão alimentar.
Os dados de altura do epitélio do duodeno, jejuno e íleo de leitões aos 36 dias de idade são apresentados na Tab. 4. Verificou-se que os tratamentos influenciaram $(\mathrm{P}<0,05)$ a altura do epitélio do duodeno, mas, não as alturas do epitélio do jejuno e do íleo. As alturas do epitélio, do jejuno e do íleo que representam os maiores segmentos do trato gastrintestinal, podem, parcialmente, explicar os desempenhos semelhantes observados para os animais alimentados com as diferentes dietas experimentais.

Observou-se que, aos 36 dias de idade, nos contrastes T1 com T2, T1 com T3, T2 com T4 e T2 com T5 não houve diferença na altura do epitélio do duodeno. Diferenças na altura do epitélio do duodeno foram verificadas nos contrastes T3 com T6 e T3 com T7 (Tab. 4).

O desenvolvimento da mucosa intestinal decorrente do equilíbrio entre a renovação celular (proliferação e diferenciação), resultante da mitose sofrida por células totipotentes localizadas na cripta e ao longo das vilosidades (Uni et al., 1998; Uni et al., 2000) e perda de células (extrusão) que ocorre normalmente no ápice das vilosidades proporcionam um turnover celular (síntese-migração-extrusão) constante. Isso sugere a manutenção da espessura do epitélio e, em decorrência, a manutenção da capacidade digestiva e de absorção intestinal. Entretanto, quando o intestino responde a algum agente, com desequilíbrio no turnover celular, favorecendo um dos processos mencionados, ocorre modificação na altura das vilosidades (Pluske et al., 1997). 
Ácido fumárico e sua combinação...

Tabela 4. Altura do epitélio $(\mu \mathrm{m})$ do duodeno, jejuno e íleo de leitões aos 36 dias de idade

\begin{tabular}{lccc}
\multirow{2}{*}{ Tratamento } & \multicolumn{3}{c}{ Altura do epitélio } \\
\cline { 2 - 4 } & Duodeno $^{1}$ & Jejuno & Íleo \\
\hline T1 - controle & $46,80 \mathrm{a}$ & 27,86 & 26,13 \\
T2 - ácido fumárico $(0,5 \%)$ & $43,10 \mathrm{a}$ & 29,86 & 24,76 \\
T3 - ácido fumárico $(1,0 \%)$ & $43,13 \mathrm{a}$ & 30,13 & 26,53 \\
T4 - ácido fumárico $(0,5 \%)+$ ácido butírico $(0,1 \%)$ & $46,00 \mathrm{a}$ & 30,86 & 27,60 \\
T5 - ácido fumárico $(0,5 \%)+$ ácido fórmico $(0,5 \%)$ & $40,23 \mathrm{a}$ & 29,23 & 26,06 \\
T6 - ácido fumárico $(1,0 \%)+$ ácido butírico $(0,1 \%)$ & $35,90 \mathrm{~b}$ & 27,83 & 24,80 \\
T7 - ácido fumárico $(1,0 \%)+$ ácido fórmico $(0,5 \%)$ & $38,10 \mathrm{c}$ & 31,00 & 25,33 \\
\multicolumn{1}{c}{ Coeficiente de variação (\%) } & 4,51 & 7,23 & 6,73 \\
\hline
\end{tabular}

Médias seguidas de letras distintas na coluna diferem entre si pelo teste $\mathrm{SNK}(\mathrm{P}<0,05)$.

${ }^{1}$ contrastes estudados: T1 com T2; T1 com T3; T2 com T4; T2 com T5; T3 com T6 e T3 com T7.

Observou-se que as vilosidades do duodeno dos animais que receberam o tratamento controle apresentaram-se alongadas, em formato de língua, com poucas deformidades, sendo classificadas como normais (Fig. 1 e 2). De modo semelhante, as vilosidades do duodeno dos
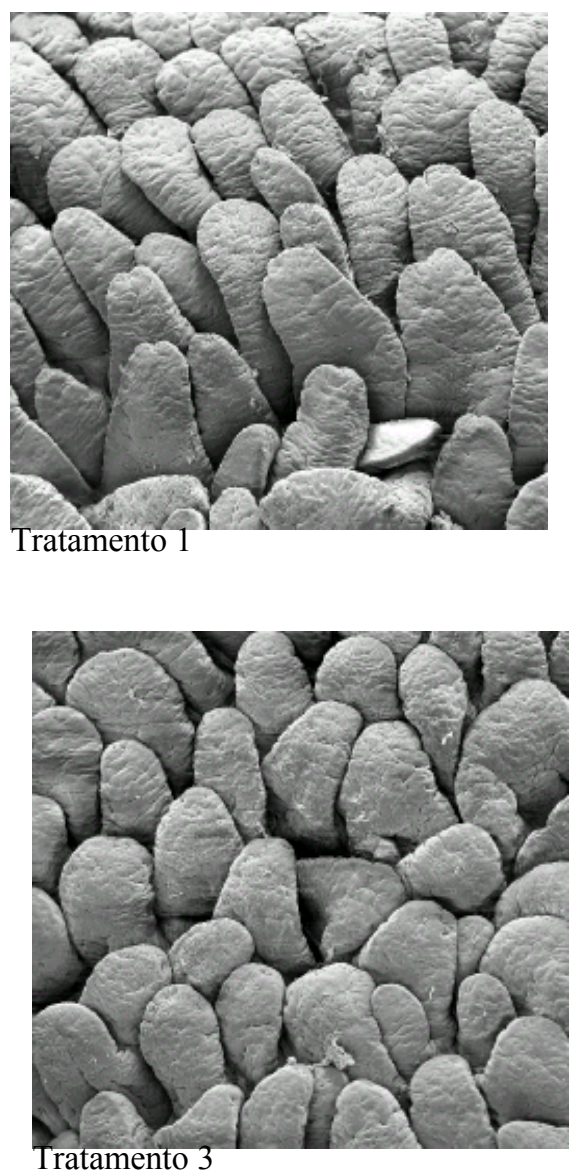

animais que receberam os diferentes tratamentos apresentaram-se com aspecto típico do segmento, ou seja, alongadas, formato de folhas, poliformismo natural, comum aos diferentes segmentos do intestino delgado.

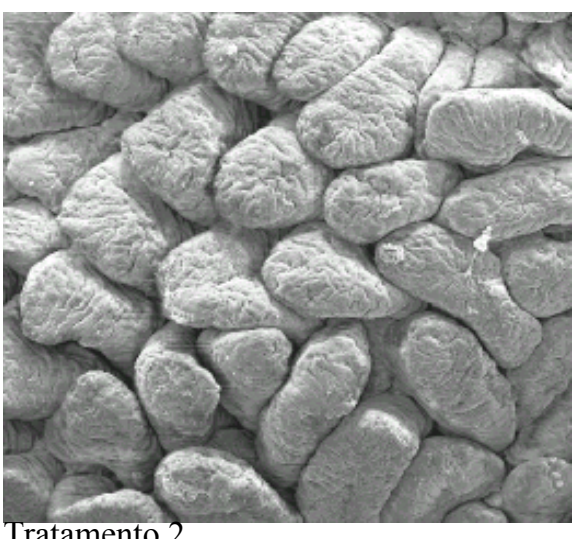

Tratamento 2

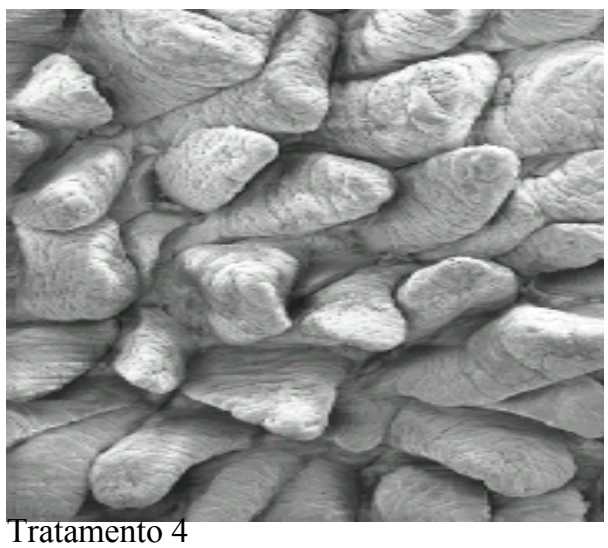

Figura 1. Eletronmicrografias de varredura das vilosidades intestinais do duodeno de leitões aos 36 dias de idade alimentados com ácidos orgânicos na ração durante toda a fase experimental. 100X. 


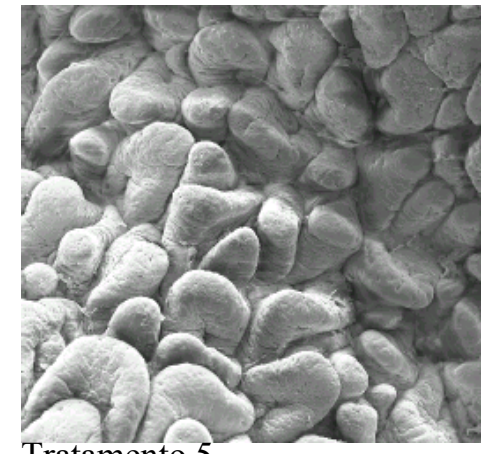

Tratamento 5

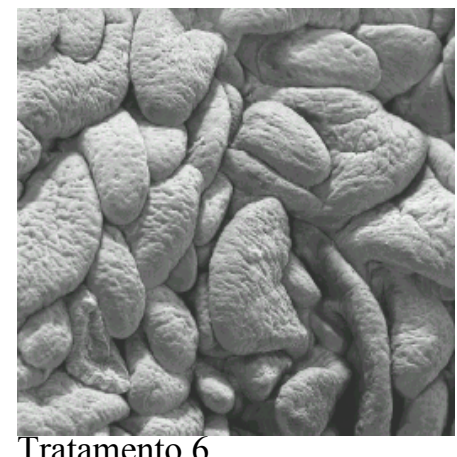

Tratamento 6

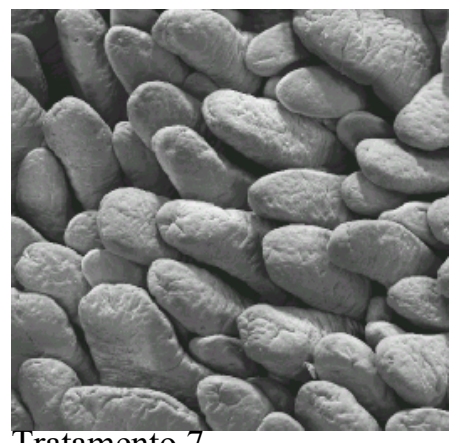

Tratamento 7

Figura 2. Eletronmicrografias de varredura das vilosidades intestinais do duodeno de leitões aos 36 dias de idade alimentados com ácidos orgânicos na ração durante toda a fase experimental. 100X.

De acordo com Macari (1995), a densidade e o tamanho das vilosidades, bem como dos microvilos, conferem características próprias a cada segmento do intestino delgado, de forma que na presença de nutrientes a capacidade de absorção é proporcional à densidade e ao tamanho das vilosidades, ou seja, à área disponível para absorção. Dessa forma, as observações na morfologia intestinal sugerem que os ácidos orgânicos utilizados neste experimento não influíram na absorção de nutrientes e nem no desempenho dos animais.

Não se observaram, em nenhum dos grupos, características de reação inflamatória severa, como presença de muco ou fibrina e nem atrofia das vilosidades.

\section{CONCLUSÕES}

A utilização de dietas suplementadas com ácido fumárico a $0,5 \%$ para leitões recém-desmamados melhora o desempenho dos animais nas duas primeiras semanas pós-desmame. A associação do ácido fumárico $(1,0 \%)+$ ácido fórmico $(0,5 \%)$ diminui o ganho de peso diário dos leitões durante o período de 15 a 36 dias de idade. A associação de $1 \%$ de ácido fumárico aos ácidos butírico $(0,1 \%)$ e fórmico $(0,5 \%)$ causa prejuízos na altura do duodeno de leitões nas primeiras três semanas pós-desmame.

\section{REFERÊNCIAS BIBLIOGRÁFICAS}

CERA, K.R.; MAHAN, D.C.; CROSS, R. F. et al. Effect of age, weaning and postweaning diet on small intestinal growth and jejunal morphology in young swine. J. Anim. Sci., v.66, p.574-584, 1988.

ETTE, T.; MENTSCHEL, K.; ROTH, F.X. Dietary self-selection for organics acids by the piglet. Arch. Anim. Nutr., v.58, p.379-388, 2004.

FALKOWSKI, J.F.; AHERNE, F.X. Fumaric and citric acid as feed additives in starter pig nutrition. J. Anim. Sci., v.58, p.935-938, 1984.

FREITAS, H.T.; FERREIRA, A.S.; LUDWIG, A. Manejo de desmame precoce de leitões. In: REUNIÃO ANUAL DA SOCIEDADE BRASILEIRA DE ZOOTECNIA, 32., 1995, Brasília. Anais... Brasília: SBZ, 1995. p.432-433 (Resumo).

GIESTING, D.W.; EASTER, R.A. Response of starter pigs to supplementation of corn-soybean meal diets with organic acids. J. Anim. Sci., v.60, p.1288-1294, 1985.

JUNQUEIRA, L.C.U.; JUNQUEIRA, L.M.M.S. Técnicas básicas de citologia e histologia. São Paulo: Universidade de São Paulo, 1983. 123p.

KIRCHGESSNER, M.; ROTH, F.X. Fumaric acid as feed additive in pig nutrition. Pig News Inf., v.3, p.259-264, 1982.

KRAUSE, D.O.; HARRISON, P.C.; EASTER, R.A. Characterization of the nutritional interactions between organic-acids and inorganic bases in the pig and chick. J. Anim. Sci., v.72, p.1257-1262, 1994.

LEIBBRANDT, V.D.; EWAN, R.C.; SPEER, V.C. et al. Effect of age and calorie: protein ratio on performance and body composition of baby pigs. J. Anim. Sci., v.40, p.1070-1078, 1976. 
MACARI, M. Mecanismos de proliferação e reparação da mucosa gastrintestinal em aves. In: SIMPÓSIO DE COCCIDIOSE E ENTERITE, 1., 1995, Campinas. Anais... Campinas, 1995 (Resumo).

McINTTYRE, A.; GIBSON, P.R.; YOUNG, G.P. et al. Butyrate production from dietary fibre and protection against large baowel cancer in a rate model. Gut. v.34, p.386-391, 1993.

MROZ, Z. Organics Acids of various origin and phisico-chemical forms as potential alternatives to antibiotic growth promoters for pigs. In: INTERNATIONAL SYMPOSIUM ON DIGESTIVE PHYSIOLOGY IN PIGS, 9., 2003, Banff. Proceedings... Banff, 2003. v.1, p.267293.

NUTRIENT requirements of swine. 10.ed. Washington: National Academic of Sciences, 1998. 190p.

OVERLAND, M.; GRANLI, T.; KJOS, N.P. et al. Effect of dietary formates on growth performance, carcass traits, sensory quality, intestinal microflora, and stomach alterations in growing-finishing pigs. J. Anim. Sci., v.78, p.1875-1884, 2000.

PLUSKE, J.R.; HAMPSON, D.J.; WILLIAMS, L.H. Factors influencing the stricture and function of the small intestine en the weaned pig: a review. Livest. Product. Sci. v.51, p.215-236, 1997.

RADECKI, S.V.; JUHL, M.R.; MILLER, E.R. Fumaric and citric acids as feed additives in starter pig diets: effect on performance and nutrient balance. J. Anim. Sci., v.66, p.25982605, 1988.

RISLEY, C.R.; KORNEGAY, E.T.; LINDEMANN, M.D., et al. Effects of organic acid with and without a microbial culture on performance and gastrointestinal tract measurements of weanling pigs. Anim. Feed Sci. Tech., v.35, p.259-270, 1991.

SISTEMA de análises estatísticas e genéticas SAEG. Viçosa: UFV, 2000.

SILVEIRA, A.M. Desempenho de leitões desmamados alimentados com rações contendo diferentes níveis de ácido fumárico. 2004. 53f. Dissertação (Mestrado) - Faculdade de Zootecnia e Engenharia de Alimentos, Universidade de São Paulo, São Paulo, SP.

UNI, Z.; GANOT, S.; SJLAN, D. Posthach development of mucosal function in the broiler small intestine. Poultr. Sci., v. 77, p. 75-82, 1998.

UNI, Z. Vitamin A deficiency interferes with proliferation and maturation of cells in the chickens small intestine. Br. Poultr. Sci., v.41, p.410-415, 2000.

YAMAUCHI, K.E.; ISHIKI, Y. Scanning electron microscopic observations on the intestinal villi in growing White Leghorn and broiler chickens from 1 to 30 days of age. $\mathrm{Br}$. Poultr. Sci., v.32, p.67-78, 1991. 